\title{
Imaginários do sensacionalismo: transferências culturais entre Brasil e França no inicio do século XX
}

The imaginary of sensationalism: cultural transfers between France and Brazil in the early twentieth century

\section{Valéria Guimarães}

Universidade Estadual Paulista "Júlio de Mesquita Filho", campus de Franca, SP, Brasil

Resumo: O objetivo é analisar narrativas sobre o sobrenatural e mostrar como o imaginário desse tema universal percorre jornais franceses e brasileiros, em diversos formatos (faits divers, crônicas literárias, crítica etc.), articulando-se ao contexto específico de recepção. Escolhemos os casos dos jornais Gazeta de Notícias do Rio de Janeiro e Le Figaro de Paris para abordar as transferências culturais entre os dois países. Ao mesmo tempo, mostramos que a circulação de temas tem múltiplas direções, passando por diversos suportes, formatos e gêneros, constituindo os imaginários do sensacionalismo que, a despeito da estandardização, podem e devem ser apreendidos historicamente.

Palavras-chave: Imaginário. Sensacionalismo. Le Figaro. Gazeta de Notícias. Transferência cultural.

Abstract: The aim of this article is to analyze narratives about the supernatural and show how the imaginary of this universal topic appears in French and Brazilian newspapers in varied formats (faits divers, literary chronicle reviews etc.) and connects the specific context of reception. We choose the cases of newspapers Gazeta de Notícias, published in Rio de Janeiro, and Le Figaro, published in Paris, to interpret the cultural transfers between the two countries. At the same time, we show that the circulation of topics has multiple directions in several media formats and genres, constituting the imaginaries of sensationalism that, despite standardization, can and should be understood historically. Keywords: Imaginary. Sensationalism. Le Figaro. Gazeta de Notícias. Cultural transfers. 


\title{
O sobrenatural: entre a magia e a ciência
}

Em abril de 1900 o jornal Gazeta de Notícias (GN) do Rio de Janeiro publicou, com destaque na capa, logo na primeira coluna, um fait divers com o título Um Curandeiro. O homem "se fazia chamar pomposamente de Conde Salvadori Della Baschiesa", mas era descrito pelo jornalista como "apenas um aventureiro, espiritista, fanfarrão, curandeiro a passar o conto do vigário" (GN, 09/04/1900). Através do texto temos sua imagem: era alto, tinha fala "melíflua" e não se poupava ao luxo, contraindo muitas dívidas. No Rio, o curandeiro estava instalado num palacete na Rua

Valéria do Catete, elegantemente mobiliado por um português de cuja esposa o Guimarães Conde Salvadori estava cuidando. Foi a morte dela "numa cura que pareceu um assassinato" que causou a intervenção policial. 0 jornal ainda 98 informa que "As sessões espíritas na casa do Catete eram muito concorridas", e que havia "tantas sociedades do gênero" que isso só podia se dar pela "ignorância de uma parcela não pequena do povo soberano [que a] alimenta fartamente".

Acompanhando o crescente interesse do público brasileiro por informações do submundo carioca, no fim de 1904, pouco mais de quatro anos após a publicação de Um Curandeiro, é lançado o livro As religiões no Rio, de Paulo Barreto (2006), conhecido como João do Rio, cujas crônicas tinham sido publicadas no jornal Gazeta de Notícias. Mantendo um diálogo aberto com as seções criminais, recheadas de faits divers, no ano de 1905 ele dá sequência ao estilo com a seção "No Jardim do Crime"

Tal foi sua repercussão, que se deu o percurso contrário, com um fait diversier (ou pequeno repórter) citando João do Rio na seção "Factos Diversos" desse jornal:

\begin{abstract}
Um Antro de Feitiçaria
Bruxedos e mandingas. Vítimas do veneno

Ainda há pouco, pela Gazeta, João do Rio desnudou a vida dos antros desta cidade contando com todas as suas cores o que é a feitiçaria praticada quase sempre por negros que fazem disso, entre eles, uma religião e para os outros, os doentes do corpo e da alma, uma profissão rendosa.
\end{abstract}

1 "No Jardim do Crime - Sob o título No Jardim do Crime começaremos a publicar amanhã um estudo impressionista sobre a Detenção, assinado por João do Rio. Todos os que conhecem as qualidades de estilo desse especialista da enquete, imaginarão decerto o que será a nova série de artigos. 0 primeiro artigo intitula-se Crimes de Amor." (GN, 27/08/1905). Essas crônicas foram posteriormente publicadas no livro A alma encantadora das ruas (BARRETO, 2005). 
Vemos agora um quadro de feitiçaria em que há vítimas, pelo menos dois conhecidos da polícia, que se meteu no coro e arrostando com todas as consequências más prometidas pelos feiticeiros, agiu energicamente contra essa perigosa gente, representada nesse caso por uma pitonisa de cor do ébano.

Este caso foi passado ou está se passando ainda no bairro que tem ocupado a atenção pública de há dias para cá - foi em Botafogo.

Há alguns meses que vivia explorando a credibilidade doentia de certa gente, uma negra de cerca de 40 anos, de nome Eufrásia Antonia Mercedes, que para isso armou sua barraca de bruxaria e mandinga, num dos cômodos da casa $\mathrm{n}^{\circ} 121$ da rua de S. Clemente, onde recebia grande quantidade de clientes. (GN, 01/01/1905, p. 2).

Imaginários do sensacionalismo

A seguir, vemos uma dessas crônicas de João do Rio, publicada em 10 de abril de 1904, na coluna "Religiões no Rio", com o título "Sacerdotisas do Futuro":

Essa gente cura, salva, desfaz as desgraças, ergue o véu da fortuna, faz esperar, faz crer, vive em prédios lindos, em taperas, em casinholas - é o conjunto das pitonisas modernas, as distribuidoras de oráculos. Em meio tão variado há de haver ignorantes - a maioria - cartomantes que veem nas cartas caminhos estreitos e caminhos largos e não sabem nem distribuir o baralho, sonâmbulas falsificadas, portuguesas e mulatas que se apropriam dos moldes dos africanos, e mulheres inteligentes que conversam e discutem.

Frequentei os templos do futuro. Só em uma semana visitei oitenta, encontrando-os sempre cheios de fiéis. O caleidoscópio alucinante das adivinhas faz a vida livremente. Em algumas casas encontrei três e quatro, girando sob uma única firma. (GN, 10/04/1904, p. 2).

O jornal Gazeta de Notícias foi fundado em 1875 e "era, realmente, jornal barato, popular, liberal, vendido a 40 réis o exemplar" (SODRÉ, 1999, p. 224). Mantinha-se com subvenções para a publicação de atos oficiais e publicidade. Teve como fundador Ferreira de Araújo, que estava acompanhado nessa empreitada por jornalistas profissionais como Manoel Carneiro, Elísio Mendes e Henrique Chaves e "não homens de letras [o que] mostrava como a imprensa brasileira conquistara características definitivas" (SODRÉ, 1999, p. 225). Mas nele vários homens de letras também estamparam seus nomes, como Machado de Assis, Olavo 
Bilac e José do Patrocínio, tornando-o conhecido como jornal sério e um modelo de jornalismo moderno para todo o país, com a adoção de técnicas inovadoras.

Ele trazia as tiragens em seu cabeçalho, como nenhum outro jornal, e ostentava a marca de ser um dos mais vendidos do Brasil, com uma tiragem de 12 mil exemplares na sua fundação, elevando esse número para 13.500 em 1876. Em 1878, o editorial anuncia na primeira página com orgulho:

Valéria

Guimarães
Continua a crescer a tiragem desta folha, que é incontestavelmente a de maior circulação no Império. Desde o princípio deste ano, com a entrada de novos assinantes e aumento da folha avulsa, a tiragem atingiu a dezoito mil exemplares, fato sem exemplo nos anais do jornalismo brasileiro. (GN, 12/01/1878).

Vemos que, embora seu sucesso também se deva ao contrato de publicação de material oficial, o aumento da venda avulsa de exemplares era o termômetro do sucesso diante do público. Temos que levar em conta ainda o fato de que um mesmo exemplar era lido por diversas pessoas, o que em muito multiplicava esses índices de consumo. Estratégias para aumentar a vendas e as assinaturas - o que significava a expansão dos anúncios - também foram usadas. Uma delas consistia na distribuição de brindes. Outra tinha como base a abertura de novos tipos de seções, sempre buscando agradar ao público cada vez mais variado.

As séries a que pertencem as crônicas de João do Rio, bem como as rubricas de faits divers, fazem parte desse esforço. Embora não fosse $o$ jornal mais sensacionalista da época, sendo ultrapassado pelos cariocas Jornal do Brasil e Correio da Manhã e pela Gazeta de São Paulo, em 1878 já apresentava a seção "Ocorrências da Rua" para notas do cotidiano, aumentando seu espaço para os faits divers de forma gradativa em rubricas específicas, como "Acontecimentos Notáveis" (1880) e "Casos Policiais" (1890), chegando a 1905 com $40 \%$ da superfície do jornal tomada por faits divers distribuídos por quatro rubricas: "Os Subúrbios", "Factos Diversos", "Ocorrências" e "Última Hora".

Notícias acerca dos fenômenos sobrenaturais eram recorrentes nos jornais da época e podem ser incluídas no que chamamos mais amplamente de faits divers de prodígios, grupo de notícias sensacionalistas 
de par com a ficção, narrativas sempre dadas como verdadeiras, independentemente de seu grau de fabulação².

Os temas de prodígio apareceram cedo na imprensa brasileira de cunho comercial, que tentava sofregamente conquistar o maior público possível dentro de um mercado letrado restrito. Em meados do século XIX, as pequenas notas tinham ainda uma relação estreita com o universo do almanaque: histórias de terror, de fantasmas ou de espíritos (maus e bons), muitas vezes em tom anedótico.

Na seção "Noticiário" do diário Correio Paulistano (CP)3 em 1870, vem uma reprise de um jornal português, o Echo Operário, jornal da Covilhã (Portugal), com o título de Afinal era um rato! Mais próximo a um causo, tal era a narrativa:

Imaginários do sensacionalismo

\section{Afinal era um rato!}

Lê-se no Echo Operário, jornal da Covilhã:

Referem-nos o seguinte fato, acontecido em uma pequena povoação deste Conselho.

Um dia ocorreu na povoação cujo nome olvidamos, que as almas de diversas pessoas que haviam morrido, andavam às soltas no cemitério.

E de fato a cousa para a gente supersticiosa apresentava-se com todos os visos de verdade.

Todas as manhãs e ao anoitecer, saía de baixo de uma pequena árvore que se achava junto da parede, uma caveira que se mexia pouco e pouco, saltava de vez em quando o que fazia arrepiar as melenas no toutiço de uns, fugir outros etc.

Os mais valentes comentavam o fato, dizendo:

- É a alma da tia Angélica que emprestava pintos por 120 réis de juros a semana.

- Essa era uma santa mulher, dizia outro: não pode ser senão a alma do

2 Dividimos os vários tipos de faits divers que apareciam nos jornais brasileiros em prodígios (fenômenos sobrenaturais; curiosidades científicas; temas circenses; gêmeas siamesas e seres fenomenais); crime (homicídios e suas variações - parricídios, fratricídios, uxoricídios etc.; suicídios; brigas, agressões e cenas de sangue em geral; roubos e assaltos, incluindo o "conto do vigário"; campanhas de higienização - contra o tabaco, o álcool, a prostituição, o caftismo etc.); e cotidiano (ocorrências de destaque na cidade - políticas, econômicas, sociais; notícias sobre guerras, revoltas ou conflitos; desastres - incêndios, inundações, acidentes).

3 É um dos mais antigos de São Paulo, de orientação conservadora. Fundado em 1831, para ser fechado um ano depois, volta a ser publicado em 1854, apresentando-se como empreendimento comercial, voltado a um público amplo e variado. Não tem faits divers antes de 1870 e só apresenta uma seção específica em 1903, "Factos Diversos". 
Manoel do ferrador que morreu sem confissão.

- Nada, disse um velhote em sentido sentencioso, é a alma de um padre que aqui existiu em tempo, que fazia cousas... se vocês soubessem...

Nesta ocasião a caveira dá um grande pulo, e oh! Sai de dentro dela um enorme rato!

Não faltaram gritos de alegria: a eles acudiu um grande número de homens que fizeram montaria ao rato, e fizeram-lhe pagar com a vida os sustos que pregou a tanta gente crédula. (CP, 30/01/1870).

Valéria É o tom anedótico que predomina. Só que, diferentemente dos Guimarães sueltos (pequena história explicitamente anedótica feita para o jornal), o caso é narrado sob a aparência de informação. A referência genérica a um lugar e dia qualquer, a alusão a fenômenos sobrenaturais, o ambiente provinciano, tudo contribui para uma composição mais próxima à ficção. Já se vê um olhar racionalista do jornalista português, que usa os termos "gente supersticiosa" e "gente crédula", mas também é possível perceber a falta de preocupação em provar para o leitor que essa era de fato uma notícia, com o uso de expressões como “povoação cujo nome olvidamos".

Apesar da aparência de ficção, esse texto foi dado como notícia. Com o passar dos anos, em uma mudança que não é linear, almas penadas, espíritos desencarnados, santos milagrosos aparecem ao lado de seus representantes na terra, como os médiuns e os feiticeiros, cuja representação oscila entre o benfeitor e o monstro, sendo esta última imagem mais comum.

A partir da leitura de uma série dessas notícias, é possível perceber como naquela sociedade havia uma forte discriminação a tais manifestações. Suas representações eram quase sempre associadas à ação dos estratos mais pobres da população retratados como criminosos, que tentavam ganhar dinheiro fácil às custas da ingenuidade alheia. E mesmo um João do Rio, que parecia querer humanizar "essa gente" e ver alguma lógica nas suas práticas, não fazia senão reproduzir os mesmos estigmas que eram alimentados por um imaginário recorrente no jornal.

Os casos específicos de Um Antro de Feitiçaria e Um Curandeiro, além de apresentarem crimes de assassinatos e logros, estavam igualmente inseridos no contexto da desconfiança e condenação jurídica das práticas mágico-religiosas. Estas eram passíveis de sanções legais, e a dificuldade em defini-las, uma vez que as tradições afro-brasileiras se 
misturaram aos novos rituais trazidos com as levas migratórias, fazia com que a polícia ficasse ainda mais vigilante (KOGURUMA, 2001). Nos grandes jornais brasileiros da época, como a Gazeta de Notícias, o combate ao curandeirismo resultou em uma ampla campanha que nada mais é que uma tradição que se inaugura na Belle Époque, as chamadas "campanhas higienizadoras" (SEVCENKO, 1989).

Assim, os perigos do além se concretizam nas imagens das "pitonisas" e seus comparsas. Em oposição ao corpo fluido do fantasma, que vinha representado nas quase anedóticas notas dos primórdios da imprensa comercial nacional, o curandeiro aparece como um homem sedutor (alto, de fala melíflua), pródigo, que se utilizava da falsa identidade para disseminar seus crimes. Curandeiro, espiritista e fanfarrão aparecem na narrativa como sinônimos. Todos em torno de "uma única Imaginários do sensacionalismo firma", como as videntes de João do Rio, verdadeiro empreendimento lucrativo e ilegal, desenrolando-se às barbas das autoridades. Assumem o papel do protetor dos bons costumes: o jornalista e o cronista, que, por vezes, são a mesma pessoa.

Os representantes da lei, como os policiais, também são figuras recorrentes nos faits divers. No nosso exemplo, eles aparecem enfrentando os feiticeiros a despeito de "todas as consequências más prometidas”. Mas delegados, escrivães e juízes também estão presentes frequentemente como figuras normativas, as quais representam a volta à ordem que foi perturbada. Por fim, os representantes da Medicina nem sempre compõem a cena, mas são constantemente evocados. Nesse caso, isso fica implícito no combate ao curandeirismo que tem nas práticas médicas científicas seu maior inimigo.

Não menos amedrontadora parecia ser a nova doutrina do espiritismo kardecista, que conhece sua difusão no Brasil por essa época e que era evocada na descrição do Conde Salvadori Della Baschiesa. Em um país com forte tradição em combater as práticas religiosas que não se alinhavam ao catolicismo, o espiritismo aparecia como nova ameaça.

Muitos aderiram a essa "religião científica" apesar das resistências da sociedade de então. Um dos principais nomes da ciência da época, Cesare Lombroso, muito influente no Brasil, dedicou-se a desmistificar e denunciar violentamente o espiritismo no opúsculo Studi sull'ipnotismo de 1882 (ALMEIDA, 2007). Tempos depois, porém, Lombroso mudou de ideia. Sujeitou-se a experiências com a médium Eusápia Paladino e escreveu um livro favorável à prática, Hipnotismo e mediunidade, de 1909, muito citado 
até hoje no espiritismo como forma de lhe atribuir lastro científico. Lombroso nele advoga a tese de que o histerismo, segundo ele uma condição do médium, favorecia a sensibilidade aos fenômenos espirituais, numa associação entre loucura e espiritismo então muito acreditada.

o hipnotismo, ainda hoje usado em alguns tratamentos psiquiátricos e terapêuticos e, portanto, pertencente à alçada da Medicina, também é citado nesse livro e colocado na mesma categoria do espiritismo, sendo que o médium muitas vezes usava os dois recursos, fundindo as imagens de cientista e feiticeiro, de médico e curandeiro, como vimos

Valéria com o tal "Conde". Essa confusão entre espiritismo e religiões de matriz Guimarães africana, no Brasil, é muito comum até hoje devido ao intenso sincretismo, caso da umbanda, que ainda inclui o catolicismo. E a identificação desses praticantes simplesmente como "espíritas" serve igualmente de combate ao estigma de "feiticeiros", "macumbeiros" e suas variáveis.

Essa aparência racional fez com que brasileiros ilustres fossem se convertendo ao espiritismo. $O$ espaço ao debate sobre o tema amplia-se nesses princípios do século XX, mas ainda oscila muito entre a condenação e a legitimidade. Nesse quesito, é pródigo o diálogo com o debate que já ocorre na França durante o século XIX, donde esse fenômeno é originário, tendo alcançado grande monta e contando entre os adeptos com um homem da estatura de um Victor Hugo. A associação do espiritismo com a modernidade encaixava-se nos ideais civilizatórios, operando uma "dissolução naturalista" do sobrenatural que agradava os seguidores dessa "fé positivista" segundo Marion Aubrée e François Laplantine (2009).

João do Rio novamente é testemunha dessa expansão do espiritismo no Brasil. Na crônica de "Religiões no Rio" (2006), "O Espiritismo", ele afirma:

O meu amigo dizia-me:

- Nunca se viu uma crença que com tal rapidez assombrasse crentes. Se o Figaro dava para Paris cem mil espíritas, o Rio deve ter quase igual soma de fiéis. O Brasil, pela junção de uma raça de sonhadores como os portugueses com a fantasia dos negros e o pavor indiano do invisível, está fatalmente à beira dos abismos de onde se entrevê o além. A Federação publicou uma estatística dos jornais espíritas no mundo inteiro. Pois bem: existem no mundo 96 jornais e revistas, sendo que 56 em toda a Europa e 19 só no Brasil! 
Apesar do tom de chiste, João do Rio tem um tratamento respeitoso ao espiritismo, seja na descrição da sede da Federação Espírita como "um grande prédio, cheio de luz e claridade" (BARRETO, 2006, p. 272), seja na das pessoas que ali buscavam a cura, a quem chamava sempre de "senhor" e "senhora", ou na dos médiuns, respeitavelmente pintados como benevolentes e cultos, "gostando de Eça de Queiroz e lendo Verlaine" ( p. 276). Isso muda na crônica seguinte depois reunida no mesmo livro (BARRETO, 2006), "Os exploradores":

Imaginários do sensacionalismo

Como vemos nesse exemplo, se o médium podia ser visto como um portador de uma capacidade divina, uma sensibilidade acima do normal, que poderia ser utilizada na cura de doenças físicas e mentais que a Medicina não dava conta de sanar, ele era também alvo de contínua desconfiança, por vezes associado a louco, por vezes a charlatão e criminoso (ALMEIDA, 2007, p. 67).

De um lado, as manifestações espíritas eram encaradas pelo cristianismo como substitutas das "possessões demoníacas" e, de outro, foram combatidas como mistificação e superstição pela ciência. Essa reação não era exclusividade brasileira. A singularidade do caso brasileiro é que, à criminalização já existente das práticas mágico-religiosas de matriz africana ou indígena, de cunho explicitamente racista, somou-se a discriminação do espiritismo, que veio a reboque de sua condenação pelos grandes nomes da ciência - até que Lombroso, entre outros, virasse o jogo já em fins do primeiro decênio do século XX (o que ocorre após a publicação das séries de crônicas de João do Rio pela Gazeta de Notícias).

De qualquer forma, o mundo dos espíritos permanecia um topos 
muito visitado pela produção popular (FERREIRA, 2010), e inúmeras narrativas literárias, além das religiosas, teriam o mundo do sobrenatural como tema. A imprensa não faz senão explorar o filão, e novamente temos aqui um fenômeno que não é exclusivo do Brasil, como veremos a seguir.

\section{Trocas culturais na imprensa}

Não é à toa que o fim do século XIX ficou também conhecido como sendo a "era de ouro" da imprensa. Nos Estados Unidos, a imprensa da virada para o século XX mudou mais na gilded age que em qualquer período anteValéria rior (SMYTHE, 2003, "Preface"). O mesmo ocorreu na França, cuja l’âge d'or apresentou um aumento sem precedentes das tiragens (CHARLE, 2004). No Brasil, é também por essa época que o mercado editorial do impresso periódico se aquece (SALIBA, 2002), ${ }^{4}$ acompanhando a expansão mundial, ainda que dentro dos padrões modestos cabíveis ao contexto particular de uma ex-colônia, onde a tônica foi a censura à imprensa por mais de trezentos anos.

As trocas culturais eram notáveis nesse ambiente transnacional propiciado pela própria natureza desses suportes periódicos, verdadeira coletânea de temas e formatos que os fazia interessantes para um público vasto e universal. Publicados em larga escala, de fácil manipulação, traduzidos ou consumidos em língua estrangeira, sua circulação física era ainda facilitada pelos avanços dos meios de transporte. Diversos tipos de mediadores eram os principais responsáveis por essa integração do ambiente intelectual, sejam eles simples viajantes, sejam comerciantes ou homens de letras.

A circulação do suporte e de seu conteúdo ganha proporções mundiais. Nesse sentido, o advento do telégrafo torna-se central, uma vez que a difusão de temas passa a ser ainda mais intensa, levando consigo representações sociais que, articuladas ao cotidiano na forma de narrativa, concretizam-se em espaço privilegiado para observar os imaginários em curso.

Seja através das "reprises", jargão do jornalismo que designa a cópia literal de trechos inteiros de um jornal, em geral com a citação da fonte original, seja através da simples reelaboração de temáticas adaptadas aos contextos de recepção sem que a origem fosse explicitada, os percursos que os textos tomavam não estavam restritos ao periódico

4 Falamos de regiões: o norte dos Estados Unidos, a capital francesa, o eixo cultural formado por Rio de Janeiro e São Paulo. Mas foram essas regióes que propiciaram o florescimento da imprensa de periódicos em seus respectivos países. 
diário. Havia um deslizamento dos mesmos, que chegavam ao jornal provindos dos mais diversos suportes e gêneros, sendo recriados tanto em estilo como em formato. Os jornais encontravam, assim, um lauto espaço de circulação, física ou não, e levavam com eles um conteúdo que percorria os mais improváveis caminhos.

Alguns desses temas eram recorrentes e suficientemente universais, como o espiritismo e a feitiçaria. Nas nossas pesquisas sobre as trocas culturais ocorridas entre França e Brasil na imprensa, pudemos observar que os temas do sobrenatural foram muito explorados por jornais franceses durante o século XIX.

No Le Figaro (FG) de 14 de setembro de 1865, por exemplo, quando era um bissemanal, o tema do espiritismo já aparece, em um texto que coloca em dúvida sua credibilidade. Voltando-se a um público que Imaginários do sensacionalismo julga esclarecido ${ }^{5}$, já com periodicidade diária, a edição de primeiro de maio de 1868 tem uma parte inteiramente dedicada a criticar o jornal Le Siècle, que faz um elogio ao espiritismo:

Senhora Bonnemère [literalmente, Boamãe] toma, hoje, no [jornal] Siècle, a defesa do espiritismo. Vocês sabem o que é o espiritismo? Quatro pessoas se reúnem em torno de uma mesa. Elas têm em sua companhia uma espécie de intermediário que é chamado de médium. (FG, 01/05/1868). ${ }^{6}$

O autor, um certo Edouard Lockroy, depois das primeiras explicações, desfere seus golpes contra o kardecismo com um divertido diálogo entre o médium e nada mais, nada menos que o filósofo cristão Santo Agostinho:

O Médium, levanta a cabeça: - Psiu! Santo Agostinho está aqui! Aqui agorinha mesmo!

Santo Agostinho, pairando sobre os dois: - Você me irrita.

5 Como em vários dos seus exemplares, a preocupação do Figaro com a concorrência do Petit Journal era perceptível na (falta de) consideração que tinham com o público popular (e numeroso!) deste jornal. Em agosto de 1865, diziam que: “La vogue désastreuse du Petit Journal n'est pas lu que par des ignorants et illettrées, vogue basée par un intelligente spéculateur, sur la platitude et la vulgarité de la rédaction." (FG, 03/08/1865, p. 4). [N. do A.: "O sucesso do Petit Journal é um desastre, ele que não é lido senão por ignorantes e iletrados, moda que tem por base uma mente especuladora, apoiada na mediocridade e vulgaridade da redação"].

6 "M. Bonnemère prend, aujourd'hui, dans le Siècle, la défense du spiritisme. Vous savez ce que c'est le spiritisme? Quatre personnes se réunissent autour d'une table. Elles ont avec elles une sorte de commissionnaire qu'on appelle médium" (FG, 01/05/1868). 
O MÉDIum: - Vamos, venha dizer bom dia a este mestre.

SANTo Agostinho, atrás da porta: - Oiê! Ah! Aqui estou!

O MéDIum, aos assistentes: - Senhores, ele está ali.

Os assistentes pensam que seria interessante fazer baixar o espírito de Voltaire. Voltaire chega. Apresenta-se Voltaire a Santo Agostinho. Eles são da mesma opinião, Santo Agostinho faz trocadilhos e Voltaire, erros de francês. [...]

Tal é o espiritismo. Parece-me bizarro que um jornal que ataca tão violentamente as superstições - e que, neste caso, não está errado - ocupe-

Valéria

Guimarães

Fica clara a postura de crítica ao espiritismo aqui. No entanto, o tema continua em suas páginas, o que dá a medida de sua importância na sociedade francesa. Em 1896, sai a edição de novembro anunciando a peça Spiritisme!, de M. Victorien Sardou, escrita especialmente para nada mais, nada menos que Sarah Bernhardt, atriz que fez um retumbante sucesso no mundo, inclusive no Brasil. Foi encenada pela primeira vez em 1897, no Teatro Renaissance, em Paris, e é conhecida por ser a primeira peça a defender publicamente o espiritismo, do qual tanto Sardou como Sarah eram adeptos. Na peça, que entrou para o Index, um médico escocês seguidor do espiritismo, retratado como "sensível", constitui-se na "antítese do médico francês", o outro protagonista. O sucessor do dramaturgo na Academia Francesa de Letras, Marcel Prévost, faz uma defesa poética do espiritismo à la une de um volume de abril de 1903 do Figaro. Esses exemplos mostram que o tema é recorrente mesmo nesse sóbrio e crítico jornal.

Notícias sobre feiticeiros também não faltavam em suas seções de Faits Divers, Nouvelles Diverses e na Gazette des Tribunaux. É o caso da viúva Druaux, condenada a trabalhos forçados por envenenar o marido e a filha em 1896. Testemunhas disseram que, pouco antes do suposto crime, ela recebera a visita de um feiticeiro chamado Leborgne, um "malfeitor",

7 Le médium, levant la tête: Pst! Saint Augustin ici! Ici tout de suite. Saint Augustin, du haut des deux: Tu m'embêtes.

LE Médium: - Allons, venez dire bonjour à ce maître.

SAINT Augustin, derrière la porte: - Coucou! Ah! Le voilà!

Le Médium, aux assistants: - Messieurs, il y est.

Les assistants pensent qu'il serait piquant de faire venir Voltaire. Voltaire arrive. On présente Voltaire à Saint Augustin. Ils sont du même avis. Saint Augustin fait des calembours, et Voltaire des fautes de français. [...] Tel est le spiritisme. Il me semble bizarre qu'un journal qui attaque si violemment les superstitions - et qui, en cela, n'a pas tort - se mêle de soutenir ces niaiseries (FG, 01/05/1868). 
e ela mesmo tinha sido vista pela vizinha colhendo ervas no jardim. 0 veneno era de tal maneira "mágico" que não teria deixado marcas nas vítimas. No inquérito era marcante a presença dos fatores sobrenaturais, inclusive nos vários testemunhos, o que acabou condenando a mulher. A falta de provas científicas, no entanto, mobiliza o Figaro, que traz os autos processuais para o jornal e expõe vários depoimentos - de pessoas comuns, mas também legistas, médicos, advogados -, entre eles alguns que reprovaram o veredicto dado à proprietária da "casa maldita", demonstrando que o caso era de intoxicação pelo gás do aquecimento e não de envenenamento por poções mágicas (FG, 26/10/1896). ${ }^{8}$

O Figaro tinha muita reputação no Brasil. Podia ser encontrado, por exemplo, no catálogo de "Assignaturas para os Jornaes Europeos" da conceituada Casa Garraux de 1876, publicado no jornal $O$ Estado de $S$. Imaginários do sensacionalismo Paulo (06/02/1876). A medida de seu prestígio pode ser dada não apenas por o anúncio estar num jornal do porte do Estado, como esse diário era chamado à época, mas também por constar na primeira seção desse catálogo, Jornaes Políticos, entre os quase setenta periódicos.

Destacamos o caso do Figaro, sobretudo porque a Gazeta de Notícias mantinha estreitas relações com ele. Em 1890, a Gazeta oferece como brinde aos assinantes uma "primorosa edição do Figaro Illustrado [...] um dos trabalhos que mais atestam os extraordinários progressos a que têm chegado as artes gráficas, em França" (GN, 24/10/1890), o que se repete no mês de dezembro do mesmo ano, quando contratam "com o Figaro de Pariz uma edição em portuguez ${ }^{9}$, de sua artística e primorosa illustração para 1891. Quer nos desenhos, quer no texto, figuram os nomes dos principais artistas e escriptores de França." (GN, 12/12/1890).

A popularidade do jornal no eixo Rio-São Paulo continua século XX adentro, sendo possível encontrá-lo para a compra em 1908, na Casa Victor, que anuncia na mesma Gazeta de Notícias seu catálogo de jornais estrangeiros, onde se encontra o Le Figaro Illustré. Era possível lê-lo em acervos públicos, como da Biblioteca Pública do Estado, tendo sido adquirido por compra no dia 15 de janeiro de 1911 (RJRSP, 1911-1925).

Acreditamos que esses dados ilustram a importância do Figaro e de

8 No Petit Journal, mais sensacionalista, não era diferente. Casos de charlatanismo e feitiçaria misturados com crimes de médicos e espíritas eram comuns, sempre oscilando entre a exploração da crença da população nos efeitos prodigiosos do além e a delação científica que deveria combater as superstições e o atraso. Tais relatos predominaram, porém, sobretudo no século XIX, cedendo espaço a um discurso cada vez mais científico no século XX.

9 Infelizmente, ainda não conseguimos localizar este exemplar. 
seus suplementos para a história da leitura da imprensa no Brasil, isso sem citar nomes famosos que liam esse jornal, tais como Lima Barreto, Machado de Assis e naturalmente João do Rio, entre outros, deixando claro seu prestígio. Lima Barreto, por exemplo, recebe de João Noronha dos Santos vários números de Figaro (ABN, 1958, v. 105, p. 50). Pela correspondência passiva de Coelho Neto ficamos sabendo através de um certo Gahisto, em 1914, que "Ce dernier quotidien [Figaro] insere des communiqués subventionnés par le gouvernement du Brésil” (ABN, 1958, v. 78, p. 24).

O jornal pode ser, então, considerado um mediador, ao ser suporte

Valéria Guimarães de notícias de ambos os países, colocando duas culturas em contato. Ou seja, as trocas eram dadas tanto pela leitura, como pelos contatos pessoais, com publicações francesas nos jornais brasileiros, mas também ocorriam no sentido contrário, pelas subvenções oficiais, por exemplo.

Nesse sentido João do Rio também pode ser considerado um passeur culturel, não só por sua admiração pelo jornalismo francês, o que ocorreu com toda sua geração, mas pela importação de algumas fórmulas que eram próprias da imprensa do hexágono. No caso específico de que tratamos, as trocas eram tão intensas entre estes dois jornais, Gazeta de Notícias e Figaro, que a morte do prestigioso colunista brasileiro foi noticiada neste último em 26 de junho de 1921: Au Brésil - la mort de Paulo Barreto. No texto, citam sua brilhante carreira na Gazeta de Notícias, com a ascensão de redator a diretor, iniciada com "une enquête à laquelle il se livra sur les religions du Rio de Janeiro [qui] obtient un succès retentissant. Cette enquête a fait l'objet d'un livre dont les éditions successives sont épuisées" (FG, 26/06/1921 apud BETING, 2008, p. 169).

De fato, entre as fórmulas francesas usadas por João do Rio estava a enquete, que era largamente empregada no Figaro e que pode ser definida como uma pesquisa de opinião que nasce da entrevista.

A interview, no entanto, não é uma invenção francesa. Ela nasce no jornal sensacionalista The New York Herald (1835), onde notícias de crime, escândalos, fofocas, desastres e esportes, contadas de forma exagerada, ocupavam várias colunas na primeira página. 0 segredo deste jornal de James Gordon Bennet era o conteúdo variado que ia desde a cobertura sensacionalista sem qualquer pudor até notas da alta sociedade (DE FLEUR; BALL-ROKEACH, 1993). Ou, como David Spencer (2007, p. 30) afirma: "Ele não tinha necessidade de publicar provas falsas da ida do homem à lua [como havia feito o Sun], pois, com o argumentou em muitas ocasiões, as grandes histórias da experiência humana estão bem 
ao seu lado." Parte integrante desse processo foi a entrevista, inventada por ele, recurso que popularizou a reportagem, tornando os correspondentes de guerra os primeiros grandes repórteres (DELPORTE 1995).

Na França, a entrevista se transforma, a começar pela diferença entre o grande repórter e o cronista dos eventos cotidianos, o pequeno repórter ou fait diversier. Este sai à caça da informação, nem sempre redige a notícia, que fica a cargo dos rubricards (os que fazem as rubricas e que inventam, completando os dados fornecidos) e não têm o prestígio de que o grande repórter goza (DELPORTE, 1995). A entrevista, então, passa a contar como um elemento da notícia e não mais um recurso externo a ela. Daí constitui-se a enquete, um tipo de pesquisa de opinião derivada da entrevista e dos procedimentos jurídicos que visam a esclarecer pontos obscuros de algum assunto, ouvindo várias pessoas, e Imaginários do sensacionalismo usadas largamente nos faits divers.

No Brasil, a rigor, o repórter já existia como profissão desde fins do século XIX e nem sempre essa separação entre o grande e o pequeno jornalista ocorria, da mesma forma que nem sempre era possível separar com clareza sua figura da do literato. 0 mesmo acontece com os gêneros do jornal. A indefinição era sua característica, e João do Rio é um dos exemplos mais claros dessa oscilação de estilo. Sempre ligado às matrizes do jornalismo internacional, inclusive francês, foi alvo de estudo que o relaciona mais diretamente a um cronista do Figaro, Jules Huret, no qual se inspiraria (BETING, 2008).

Os faits divers da mesma forma não escapam a essa ambiguidade - aliás, característica básica dessa imprensa em formação (THÉRENTY, 2007) - e seus temas facilmente transitam nesse espaço transatlântico que se torna compartilhado entre Brasil e França (mas também Inglaterra e Estados Unidos) ou entre Gazeta de Notícias e Le Figaro, entre seus jornalistas-homens-de-letras, enfim, entre a literatura e o jornalismo.

Mas, se simplesmente admitíssemos que o jornal brasileiro copia e adapta certos temas, teríamos que assumir que essas narrativas não são históricas e que a afirmação de que a influência francesa não passava de uma cópia seria verdade. É a isso que gostaríamos de nos contrapor, demonstrando um pouco como se dão essas transferências culturais.

\section{Objetos sem história?}

Um exemplo comum de imprensa sensacionalista é aquela que se aproveita do escândalo para sua prosperidade. Aqui, os faits divers 
ocupam lugar de destaque. Antes, porém, cabe um aparte sobre a natureza desses textos, uma vez que os faits divers não eram objeto de estudo da disciplina História.

A análise mais famosa sobre o tema é a do semiólogo francês estruturalista Roland Barthes (1964), que os classificava como pertencentes ao mundo da exceção, meros fatos sem contexto, portanto a-históricos. Ele tentou identificar as estruturas fundamentais do fait divers, tendo como base a ideia de fórmula pautada pela universalidade, causalidade aberrante, ação providencial e oposições. Outros autores,

Valéria Guimarães como George Auclair (1970), retomam o tema pelo mesmo viés.

Foi em meio à gestação da nova história cultural, mais precisamente da terceira geração da chamada Escola dos Annales, que o tema do fait divers passou a suscitar a reflexão de historiadores - no que diz respeito à historiografia francesa, ao que tudo indica, pioneira nesse assunto. Entre os novos objetos da historiografia, estavam, enfim, essas pequenas notas, aparentemente imutáveis e sem importância para o estudo dos processos históricos. Na revista Annales. Économies, Sociétés, Civilisations de 1983, foi publicado um dossiê intitulado Fait divers, Fait d'histoire (1983) - quase vinte anos após as reflexões de Auclair e Barthes. Nesse dossiê da revista francesa, autores como Marc Ferro e Michelle Perrot questionam a qualidade de meramente essenciais atribuída aos faits divers pelos estruturalistas.

$\mathrm{Na}$ apresentação, este historiador afirma:

A esta concepção, muitas correções se impõem. Certamente, o fait divers é um sintoma [no sentido linguístico de índice] mas cuja significação pode variar no tempo e segundo as culturas. Ou seja, a natureza do fait divers pode igualmente se modificar, exatamente como pode evoluir a relação do fait divers com o corpo social, sua função e seu funcionamento. A história do fait divers comporta assim muitas variáveis. (FERRO, 1983, p. 822).

As perspectivas abertas por Marc Ferro para o estudo do sensacionalismo nas notícias de jornal respondiam às inquietações de historiadores da leitura que viam na imprensa, mais precisamente na imprensa popular, um objeto legítimo de estudo.

No dossiê supracitado, Michelle Perrot também publicou o artigo Fait divers et histoire au XIX ${ }^{e}$ siècle, em que expõe as linhas mestras dos tópicos que norteariam as abordagens ainda hoje em voga. Ela acentua a 
importância das invariáveis encontradas nos textos populares, as quais, observadas na longa duração, colocam em evidência seus medos e

\begin{abstract}
suas modulações no tempo e as mudanças nos seus modos de expressão. A perenidade do crime lhe importa menos que suas singularidades sucessivas, a evolução de sua mise en scène, a modificação da fisionomia criminal, a natureza sutil das relações de atração e repulsa que ele estabelece com o público. (PERROT, 1983, p. 911).
\end{abstract}

Um de seus alunos deu sequência a alguns desses debates, principalmente no que se refere ao mundo do crime: Dominique Kalifa. No seu livro L'encre et le sang (1995), resultado de sua tese de doutorado orientada pela própria Michelle Perrot, ele aborda o fait divers como parte de um conjunto midiático, "objetos de práticas culturais e reveladores do imaginário coletivo" (POIRRIER, 2004, p. 178).

Seguindo essa orientação, e sem descartar o componente estrutural do que Barthes nomeou como uma mitologia da modernidade, é a historicidade que nos interessa, bem como a compreensão de como essas pequenas narrativas do cotidiano fazem parte da construção da sociabilidade em um momento de formação de uma opinião pública, difundindo imaginários através de suas representações. A exemplo de Anne-Claude Ambroise-Rendu (2004), tentar entender essa "poética que não é mais a nossa".

Tomando como ponto de partida o fato de que o que vem na notícia (texto, ilustrações, fotos) não é a realidade em si, mas uma imagem da realidade, trabalhamos com as representações que nelas aparecem, compondo, assim, os imaginários do sensacionalismo nos jornais pesquisados. Estes tinham um elemento comum dado pelo caráter universal dos temas, mas esse não era o único motivo por trás dessa intensa e quase simultânea circulação que permitia criar referências compartilhadas. A novidade era que o caráter do jornal em fins do século XIX propiciava esse quadro, facilitando e até estimulando os percursos anteriormente descritos, alimentando a construção desse espaço euro-americano do impresso (COMPAGNON, 2009).

E a mera influência também é descartada quando pensamos nesse espaço comum, quase que simultâneo, onde fórmulas inventadas em dada região rapidamente ganham características próprias em outras,
Imaginários do sensacionalismo 
mesmo em narrativas tão estandardizadas como o fait divers, que, como vimos neste item, também são históricas.

\section{Imagens do medo}

o fait divers nem sempre é uma correspondência direta com os ocorridos que noticia - mas é um indicador simbólico das inquietações e dos valores compartilhados por uma sociedade.

Acreditamos que as notícias do cotidiano são fontes importantes de acesso ao imaginário social (SOULET, 2009), o qual é erigido sobre a multi-

Valéria plicidade de figuras da memória de uma determinada sociedade ou grupo social, ou seja, pelas representações que, sendo históricas, não podem ser reduzidas à essência. Essa posição se contrapõe àquela que defende a distinção entre uma objetividade das estruturas e a subjetividade das representações, portanto. Trabalhamos com o que é recorrente, sim, mas como essa recorrência é interpretada e utilizada em cada contexto (BOIA, 1998).

$\mathrm{Na}$ "cultura de almanaque" que predominava nos faits divers brasileiros de prodígios, as figuras da ameaça são ligadas ao mundo religioso: espíritos, almas penadas de usurários, mortos sem confissão e padres pecadores. Corpos fluidos, como fantasmas, são imagens mais próximas de um mundo rural no qual o almanaque circulava. Os monstros e as deformidades que sempre habitaram o imaginário da humanidade passam a compor os jornais em uma releitura das antigas imagens ameaçadoras. Os prodígios opõem os benfeitores aos monstros, colocando no mesmo plano os eventos naturais (um rato na caveira) e sobrenaturais (almas penadas). o lugar da ameaça ainda não é a cidade, mas um povoado distante e inominado, uma cidadezinha no interior, ou um lugar transcendente, como o céu, que situa esses fenômenos para além das capacidades cognitivas, expondo a fragilidade dos seres humanos na Terra - e uma leitura mais fantástica que racional.

É bastante compreensível que os medos sejam predominantemente dos entes do além em um cenário de relativa tranquilidade. Quando as cidades crescem e outros problemas passam a fazer parte do dia a dia, esses medos que podemos chamar de "tradicionais" são redimensionados sob a midiatização da produção serial. E a racionalização crescente resulta na ânsia por explicar, nomear, classificar, generalizar e compreender.

Isto posto, as figuras da ameaça começam a se tornar mais concretas - como os intermediários entre os mortos e os vivos, entre o céu 
e a terra, os médiuns - e, assim, reaparecem as figuras do feiticeiro e da bruxa na pele de curandeiros e pitonisas. Uma "perigosa gente" cuja representação é confusa, oscilando entre o bem e o mal, entre as imagens da cura, como o médico, ou do assassino e aproveitador, como o charlatão.

o espiritismo só vem tornar esse panorama mais complexo, aproximando a figura do médium ora do cientista, ora do prestidigitador, não raro embalado pela morfina ou pela pura e simples loucura, a personificar o demônio na sua mais bela aparência fáustica - de fala melíflua e ricamente trajado.

Os locais do perigo são cada vez mais próximos daquele da marginalidade urbana: os terreiros em que se realizam as sessões espíritas, os antros ou casas de cômodos que abrigam os ditos farsantes e tantos outros tipos marginais. Esses elementos concretos (figuras da ameaça encarnados Imaginários do sensacionalismo em pessoas e locais que jogam com elementos reais) são retirados da leitura mais atenta do fait divers quando vistos como objeto da história.

No jornal do século XIX, o fait divers inaugurou a narração do mundo como espetáculo, fornecendo junto à imprensa as matrizes do sistema de informação do século XX. E é justamente o "paradigma da visibilidade total” (AMBROISE-RENDU, 2004, p. 15) que predominará após sua entrada triunfal na modernidade. o fait divers é pan-óptico, como diz Anne-Claude, retomando Foucault.

Importante frisar dois aspectos: o primeiro é que, em termos ideológicos, esse tipo de produção midiática - faits divers, folhetins etc. - é acusado frequentemente de alienante, ópio do povo, veneno para a alma. É visto como ameaça ao civismo e à consciência de classe. A Teoria Crítica de Adorno e Horkheimer difundiu a ideia de que essas narrativas “alienantes" estariam a serviço da dominação ideológica (LIMA, 2005).

Jacques Migozzi (2011) se pergunta o porquê de essas narrativas populares serem por tanto tempo estigmatizadas, como ele diz, por uma "elite". Uma condenação aos "maus gêneros" que se estende à ideia de um leitor frágil e ingênuo - que não consegue separar realidade e ficção e que está sujeito aos ditames do texto. Ele supõe que essa repulsa revela um sintoma inquietante: o pavor de uma elite ao acesso em larga escala à leitura - a revolução silenciosa que foi possível graças à alfabetização, no caso europeu. Esse discurso de crítica aos produtos da estandardização foi bastante repetido no Brasil, malgrado os contextos diversos.

De acordo com abordagens mais recentes, a narrativa para o consumo de massa não se resume apenas à diversão ou à alienação da reali- 
Valéria

Guimarães

dade - embora este seja um dos seus principais aspectos aparentes. Ela também instrui, analisa, informa e intervém no espaço público e na sociabilidade, tanto que encontra altíssima recepção por seu público. No caso do recorte espaço-temporal escolhido para este artigo, esse leitorado era composto por um grupo significativo, que não deve ser ignorado e cuja demanda por variados artefatos culturais era crescente, acompanhando uma tendência mundial que não deixou as grandes cidades brasileiras de então, Rio de Janeiro e São Paulo, excluídas. E os autores/jornalistas se apoiavam nesses textos sedutores para passar sua informação.

O segundo aspecto que queremos observar é que não vemos o imaginário como reflexo ou cópia do real. Ele remete ao real, mas também pode ser entendido como aquilo que "comporta também utopias e elaborações mentais que figuram ou pensam sobre coisas que, concretamente, não existem" (PESAVENTO, 2008, p. 47). o imaginário traduz a experiência do "vivido e do não vivido, ou seja, do suposto, do desconhecido, do desejado, do temido, do intuído" (PESAVENTO, 2008, p. 47). Afinal, o faits divers coloca-se entre a problemática da fabulação e da referencialidade documentária (MIGOZZI, 2011). Nem alienação nem espelho: a notícia é construída pela sociedade e também a constrói, em uma interação que se autoalimenta.

\section{Faits divers no Brasil e modernidade}

Ora, a atenção que suscitou o fait divers na historiografia francesa não é gratuita. Fenômeno de grande centralidade nessa cultura, tem marcada na própria designação sua origem, uma vez que até hoje ainda é usado o termo em francês (fait divers) no jargão jornalístico universal para definir essa espécie de notícia que comporta uma boa dose de ficção. Sabemos que esse tipo de narrativa não é exclusividade francesa, tendo mesmo surgido como fórmula na imprensa inglesa e logo tomado rumos particulares no mundo anglo-saxão, sobretudo nos Estados Unidos. Mas foi na França que se tornou um novo gênero do jornalismo, ganhando ares de análise sociológica, tendo como referência os tradicionais canards ou as nouvelles, bem como os folhetins.

$\mathrm{O}$ intenso comércio de jornais franceses para o Brasil durante a passagem do século XIX para o XX garantiu que a fórmula conhecesse, aos poucos, sucesso entre os leitores nacionais, e a recente imprensa nacional de cunho comercial adotou a rubrica de forma contínua e irreversível, tal como já havia feito com o folhetim (MEYER, 1996). 
Os temas nele abordados têm relação com as discussões que se colocavam no cotidiano das respectivas sociedades. Mas, devido às características da cultura midiática que já vai se consolidando desde meados do século XIX, muitos dos debates passam a ser compartilhados por diferentes culturas nacionais, ultrapassando essas fronteiras. $\mathrm{E}$ isso é possível não por um mecanismo de cópia puro e simples. Mas pelo fato de vários dos temas já estarem presentes na produção cultural universal, como o sobrenatural. Quando midiatizados pelos impressos periódicos, dos almanaques aos jornais de larga circulação, das anedotas aos faits divers, encontram um campo fértil pronto a acolhê-los.

Dessa forma, é possível entender o porquê de, com o passar dos anos, quase todos os grandes jornais brasileiros se renderem ao sensacionalismo dos fait divers. Apenas a ideia de cópia não explicaria essa Imaginários do sensacionalismo expansão mundial do gênero. Certamente jogam um importante papel os anseios de se equiparar à modernidade europeia, mesmo que seja apenas através de suas representações. Mas também é fundamental a identificação com os temas em seu contexto: nas cidades em que a necessidade da informação midiática era maior, como grandes cidades em processo de crescimento, a exemplo de São Paulo e Rio de Janeiro, havia uma demanda pela explicação de um mundo em constante mudança a que essas narrativas do cotidiano respondiam.

A sede de descrição da modernidade, de tudo ver, tudo saber, tudo analisar, encontrava, assim, tanto na literatura de um João do Rio como nos faits divers um lugar de expressão. Ora, estes abriam uma janela para o submundo desconhecido dos leitores.

Esse trânsito pelas regiões do grotesco da sociedade causa repulsa ao "bom gosto", mas não é suficiente para impedir o voyeurismo propiciado por essas notícias recheadas de detalhes que tanto a imaginação do jornalista como a do leitor encarregavam-se de completar. 0 mesmo ocorre com as narrativas do sobrenatural, principalmente quando elas se relacionam com a criminalidade.

Não era o mundo do trabalho e seus conflitos sociais que estavam em questão, mas a sobrevivência de um imaginário que legava a tais práticas o interdito. E ele é retomado sob a linguagem da descrição exaustiva - que lembra a ânsia de domínio dos inquisidores sobre os suspeitos e que não tinha a função única de controle, mas também a intenção de aprendizado sobre o misterioso e ameaçador mundo da magia popular.

No Brasil, as sobrevivências africanas eram frequentemente as- 
sociadas ao imaginário medieval difundido pela Inquisição, como os sabás (do hebraico, shabbaths), orgias e encontros diabólicos (SOUZA, 1986). O poder do mau olhado, da mandinga, de maldições e de encantamentos era crença difundida na longa duração que ganha expressão renovada na dimensão do cotidiano midiatizado. Da mesma forma que se acreditava que a magia poderia ser usada para a cura e outros fins, como enriquecimento, vingança, previsão do futuro etc. - o que pode explicar a conivência de todo tipo de pessoa com suas práticas, inclusive as de projeção social -, o medo gerado pelos supostos efeitos negativos

Valéria não era pequeno.

Guimarães

É o que ocorre com Conde Salvadori, as videntes ou a "pitonisa" Eufrásia: a despeito de tais práticas serem legal e moralmente condenáveis pelos códigos da época, há uma rede de clientes que delas usufrui, contribuindo para sua existência e proteção. Portanto, a repressão higienizadora que visa a banir as práticas tradicionais do espaço público da cidade moderna contava com a cumplicidade estabelecida pela tradição que abria, assim, brechas para que essas práticas sobrevivessem como resistências.

Suas representações têm larga circulação, e o aparato civilizatório se esforça por identificá-las imediatamente a rituais de magia de forma negativa, num contexto racista em que os rituais eram ligados a ações deletérias e identificados prontamente à cultura popular tradicional que se quer afastar do ambiente da cidade.

Nesse contexto, jornais, jornalistas e cronistas exercem o papel de mediadores, fazendo a ligação entre duas (ou mais) realidades que encontravam um ponto de convergência nas representações coincidentes para esses temas, representações essas que ganhavam cores próprias no contexto de recepção a fim de ganhar legibilidade, sem perder seu caráter universal.

Os percursos das transferências culturais vão se revelando mais complexos, e pudemos ver como essa "tradução cultural" (BURKE; HSIA, 2009) dos imaginários do sensacionalismo se expressa em vários tipos de gêneros, bem como de suportes, encontrando, porém, um amplo espaço para sua difusão na imprensa comercial que viceja na passagem para o século XX.

\section{Referências}


ALMEIDA, Angélica Aparecida Silva de. Uma fábrica de loucos: psiquiatria x espiritismo no Brasil (1900-1950). 2007. $232 \mathrm{f}$. Tese (Doutorado em História)-Universidade Estadual de Campinas, Campinas, 2007.

AMBROISE-RENDU, Anne-Claude. Petits récits des désordres ordinaires: les faits divers dans la presse française des débuts de la IIIe République à la Grande Guerre. Paris: Éditions Seli Arslam, 2004.

AUBRÉE, Marion; LAPLANTINE, François. La table, le livre et les Imaginários do esprits: naissance, évolution et actualité du mouvement social sensacionalismo spirite entre France et Brésil. Paris: J.C. Lattès, 1990.

AUCLAIR, George. Le Mana Quotidien: structures et fonctions de la chronique des fait divers. Paris: Éditions Anthopos, 1970.

BARRETO, Paulo (João do Rio). A alma encantadora das ruas. São Paulo: Cia. das Letras, 2005. (Organização de Raúl Antelo).

As religiões no Rio. São Paulo: J. Olympio, 2006. (Apresentação de João Carlos Rodrigues).

BARTHES, Roland. Structure du fait divers. In: Essais critiques. Paris: Seuil, 1964. p. 188-198.

BETING, Graziella. João do Rio et Jules Huret, parcours croisés: deux journalistes sur la route France-Brésil à la Belle Époque. Master Recherche Sciences Politiques et Sociales - Université Paris II - Panthéon Assas, dir. Fabrice d'Almeida, juin 2008.

BOIA, Lucian. Pour une histoire de l'imaginaire. Paris: Belles Lettres, 1998.

BURKE, Peter; HSIA, R. Po-chia (Org.). A tradução cultural nos primórdios da Europa. São Paulo: Ed. da Unesp, 2009.

CHARLE, Christophe. Le siècle de la presse (1830-1939). Paris: Seuil, L'Univers Historique, 2004. 
COMPAGNON, Olivier. L'Euro-Amérique en question. Nuevo Mundo Mundos Nuevos, Debates, 2009.

De FLEUR, Melvin L., BALL-ROKEACH, Sandra. Teorias da comunicação de massa. Rio de Janeiro: J. Zahar, 1993.

DELPORTE, Christian. Histoire du journalisme et des journalistes en France (du XVII ${ }^{\mathrm{e}}$ siècle à nos jours). Paris: Presses Universitaires de France, 1995. (Collection Que sais-je?).

Valéria

Guimarães ESPAGNE, Michel. Les transferts culturels franco-allemands. Paris, PUF, 1999, col. Perspectives Germaniques.

FERREIRA, Jerusa Pires. O Livro de São Cipriano: uma legenda de massas. SP: Perspectiva, 1992.

Cultura das bordas: edição, comunicação, leitura. São Paulo: Ateliê Editorial, 2010.

FERRO, Marc. Présentation - dossier Fait divers, Fait d'histoire. Revue Annales. Histoire, Sciences Sociales, v. 38, n. 4, p. 821-826, 1983.

KALIFA, Dominique. L'encre et Le sang: récits de crimes et société à la Belle Époque. France: Éditions Fayard, 1995.

KOGURUMA, Paulo. Conflitos do imaginário: a reelaboração das práticas e crenças afro-brasileiras na "metrópole do café" - 18901920. São Paulo: Annablume, 2001.

LIMA, Luiz Costa (Org.). Teoria da cultura de massa. São Paulo: Paz e Terra, 2005.

MEYER, Marlyse. Voláteis e Versáteis, de variedades e folhetins se fez a chronica. Boletim Bibliográfico Biblioteca Mário de Andrade, São Paulo, v. 46, n. 1-4, jan./dez. 1985.

Folhetim: uma história. São Paulo: Companhia das Letras, 1996. 
MIGOZZI, Jacques. Idéologie et stratégies argumentatives dans les récits imprimés de grande consommation. XIXe - XXIe siècles. Balises luminaires. Revue Belphegor, v. 9, n. 1, 2011.

PERROT, Michelle. Fait divers et histoire au XIX ${ }^{\mathrm{e}}$ siècle. Dossier Fait divers, Fait d'histoire. Revue Annales. Histoire, Sciences Sociales, v. 38, n. 4, p. 911-919, 1983.

PESAVENTO, Sandra J. História e história cultural. Belo Horizonte: Autêntica, 2008.

Imaginários do sensacionalismo

POIRRIER, Philippe. Les enjeux de l'histoire culturelle. Paris: Éditions du Seuil, 2004.

SALIBA, Elias Thomé. Raízes do riso: a representação humorística na história brasileira: da Belle Époque aos primeiros tempos do rádio. São Paulo: Companhia das Letras, 2002.

SEVCENKO, Nicolau. Literatura como missão: tensões sociais e criação cultural na Primeira República. 3. ed. São Paulo: Brasiliense, 1989.

SMYTHE, Ted Curtis. The gilded age press (1865-1900). Westport: Praeger Publishers, 2003.

SODRÉ, Nelson Werneck. História da imprensa no Brasil. Rio de Janeiro: Mauad, 1999.

SOULET, Jean-François. L'histoire immédiate: historiographie, sources et méthodes. Paris: Armand Colin, 2009.

SOUZA, Laura de Mello e. 0 diabo e a Terra de Santa Cruz: feitiçaria e religiosidade no Brasil Colonial. São Paulo: Companhia das Letras, 1986.

SPENCER, David. R. The yellow journalism: the press and America's Emergence as a World Power. Evanston, Illinois: Northwestern University Press, 2007. 
THÉRENTY, Marie-Ève. La littérature au quotidien: poétiques journalistiques au XIX ${ }^{\mathrm{e}}$ siècle. Paris: Éditions du Seuil, 2007.

\section{Outras fontes}

Jornais

\section{Brasil}

\section{Valéria Rio de Janeiro}

Guimarães

Gazeta de Notícias (GN) - 1875-1930.

122

Jornal do Comércio (JC) - 1827-1920.

O Repórter (OR) - 1879.

Jornal do Brasil (JB) - 1891-1930.

Correio da Manhã (CM) - 1901- 1930.

\section{São Paulo}

Correio Paulistano (CP) - 1854-1930.

O Estado de S. Paulo (OESP) - 1875-1930.

Diário Popular (DP) - 1884-1930.

A Gazeta (AG) - 1906-1930.

\section{França}

Le Figaro (FG) - 1850-1910.

Le Petit Journal (PJ) - 1854-1910.

\section{Catálogo}


RJRSP. Registro de Jornais e Revistas - São Paulo - 1911-1925 e 1926-1934.

Anais

ABN. Anais da Biblioteca Nacional - Rio de Janeiro - 1958.

\section{Relatório}

ALMEIDA, José Cardoso. Relatório apresentado ao Secretário do Imaginários do Interior e da Justiça pelo Chefe de Polícia de S. Paulo. São Paulo: sensacionalismo Typographia do Diário Oficial, 1903. 